\title{
More Uranium Found in Britain
}

THE Institute of Geological Studies reported this week that uranium is to be found in North Wales, the Southern Pennines, the South Wales coalfield, the Midlands as well as in the north of Scotland and south west England. (Uranium Mineralisation. . ., S. H. U. Bowie, D. Ostle and C. B. Campbell, IMM Applied Earth Science Transactions Section B, November 1973.)

Deposits in Scotland and in south west England have been previously reported by the IGS. A few thousand tons of uranium in the oxide form, $\mathrm{U}_{3} \mathrm{O}_{8}$ are to be found in Caithness and Orkney and a few hundreds of tons in the south west of England.

The extent of the deposits now found in Wales and other parts of England are not revealed but the strength, in terms of parts per million of uranium ore, makes it clear that the deposits are at present not of economic significance. But they represent reserves, which if they turn out to be of sufficient tonnage, might well prove to be of strategic importance. The possibility of mining these deposits will not arise until the high quality ore at present being mined in Canada and South Africa are worked out and the cost of ore inexorably rises.

The deposits in the Orkneys are low grade and widespread but Dr Bowie and colleagues report that in places the content of uranium in phosphatic rock is as high as 1,000 parts per million, amounting to $0.1 \%$ enrichment, which compares favourably with the quality of uranium ore now being mined in other parts of the world. But the uranium content of the dark shales in the Orkneys rarely exceeds 200 parts per million. In the south west of England, however, the ore is found in high grade concentrations but of low tonnage. The new survey revealed, however, several new sources of uranium but they are also of modest tonnage or low grades. At Fingle Bridge, a rich zone has been found of $0.5 \%$ enrichment which is over 5 feet wide.

At Lutton on the western side of Dartmoor a vein has been found which is one foot wide, and a sample analysis showed that the uranium content was of the order of $3 \%$. This same vein contains also copper, lead, silver and arsenic.

Several other sources of uranium have been found in the south west of England but the full extent of some of the deposits can not be revealed unless drilling takes place.

The present survey was restricted to sampling of stream water, sediment, wells and boreholes. When the terrain was suitable the countryside was scanned for evidence of radioactivity by carrying scintillation counters in vehicles and in some place by scanning for radioactivity on foot.

Of the newly reported finds of uranium, the IGS team reports that although some uranium is to be found in North Wales, it is not of economic grade. "The rocks represent a major crystal enrichment but no evidence has yet been found of uranium concentrations sufficient to produce deposits of potential value."

The uranium concentrations in the southern Pennines are very low (10-30 parts per million) but in the South Wales coalfield, concentrations of $270 \mathrm{ppm}$ have been found. It is unlikely, however, that the element is present here in sufficient quantities to be of economic significance, according to Dr Bowie and colleagues. The highest concentration

STEEL

\section{European Opportunilies}

An improved coordination of steel research within Europe was called for by Dr Robert S. Barnes, director of research and development at the British Steel Corporation, last week. Dr Barnes, delivering the annual Hatfield memorial lecture, said that "the need to exchange technical views, to criticise, construct and develop cooperatively concepts for joint European research activity is now more necessary than ever it was".

Dr Barnes was critical of the arrangements existing at present within Europe for collaborative research in steel. The task of processing and assessing the waves of uncoordinated and untranslated proposals which sweep through the EEC and its advisory committees several times a year is too great, according to Dr Barnes. "The commission's advisory committees--there must be about a hundred of these--only deal with narrow technical areas and are often more concerned with technical details rather than with the broad needs for the individual research projects or with the eventual application of their outcome."

There is therefore a need for efforts to be concentrated on a few clearly defined and large projects, which for one of uranium found in the Midlands amounted to $162 \mathrm{ppm}$ and this is in a shallow peat deposit.

No marked radioactivity was found in extensive examinations across the Midlands, from the Welsh borderland in Montgomeryshire and Radnorshire to Lincolnshire and Nottinghamshire except for some activity near the known outcrop of Cambrian shale near Nuneaton.

Uranium has never been mined on a large scale in Britain although it was obtained as a by product of a pitch blend mine near St Austell earlier this century. Britain, however, is not likely ever to produce enough uranium to fulfill its needs. The nuclear reactors at present in operation in Britain need more than a thousand tons of uranium a year to keep them in production. When it does become economic to think of mining uranium in Britain then the reported reserves (a few thousand tons of $\mathrm{U}_{3} \mathrm{O}_{8}$ ) represent at the present rate of usage, a few years' supply.

thing would ease the communication and administrative problems of steel research in Europe, said Dr Barnes.

In order to achieve these objectives, the European Commission will have to be advised in a different way. At present the commission's advisory experts are appointed as individuals and it would be advantageous if these experts represented the collective view of the European steel industry. Dr Barnes called for the industry to set up just such an organisation which would "produce and regularly update a strategy for collaborative research". It is possible that l'Association Européene pour la Promotion de la Recherche Technique en Siderurgie could fill this role.

Dr Barnes also highlighted in his lecture a possible way of making steel in the future by using the gas emitted from a High Temperature Nuclear Reactor as a reducing agent. The gas would first be used to convert the iron ore to a pre-reduced iron. This would then be fed to an electric arc powered by electricity obtained from the waste heat of the first process.

Such direct use of nuclear power could be the way in which most steel will be made in the twenty-first century. It could, however, be introduced even sooner if the costs of using other forms of energy, such as coal or electricity, escalate faster than anticipated. 